\title{
Assessment of Genotype and Molecular Evolution of Hepatitis C Virus in Formalin-Fixed Paraffin-Embedded Liver Tissue from Patients With Chronic Hepatitis C Virus Infection
}

\author{
Carolina Soguero, Elías Campo, Teresa Ribalta, José María Sánchez-Tapias, \\ Juan Carlos Sáiz, and Miguel Bruguera
}

Liver Unit (CS, JMS-T, JCS, MB), Institut de Malalties Digestives, Department of Medicine; and Department of Pathology (EC, TR), Hospital Clínic Institut d'Investigacions Biomèdiques August Pí i Sunyer (IDIBAPS), Universidad de Barcelona, Barcelona, Spain

SUMMARY: Drawbacks of hepatitis C virus (HCV) RNA detection in paraffin-embedded liver tissue have satisfactorily been solved by RT-PCR amplification of the 5'non-coding region (5'NCR). However, detection of this highly conserved region does not provide information on epidemiological or pathogenetic aspects of HCV infection. This study explores whether other functionally important genetic regions of $\mathrm{HCV}$, such as the hypervariable region 1 (HVR-1) and the interferon sensitivity-determining region (ISDR), can be retrieved from paraffin-embedded liver specimens by RT-PCR, and whether the amplified material is suitable for further molecular analyses. RT-PCR amplification of 5'NCR, HVR-1, and ISDR was assessed in RNA extracted from 50 formalin-fixed, paraffin-embedded liver specimens, including 23 needle liver biopsies (11 from patients with non-A, non-B chronic hepatitis diagnosed between 1971 and 1985, 8 from subjects with normal liver histology and 4 from sequential biopsies from a patient with HCV recurrence after liver transplantation), and 27 liver explants from patients undergoing transplantation between 1988 and 1996 (16 with HCV-related cirrhosis and 11 with other disorders). The 5'NCR was successfully amplified in 8 of 11 (73\%) non-A, non-B chronic hepatitis biopsies and in all of the specimens from patients with serological documentation of HCV infection. There were no false-positive results. HCV genotype was identified by RFLP analysis of the $5^{\prime} \mathrm{NCR}$ in the 13 cases analyzed. HVR-1 and ISDR were amplified in 24 of $28(86 \%)$ samples, which were positive for the $5^{\prime}$ NCR. Efficient amplification was inversely related to the time of storage. The evolutionary changes of HVR-1 and ISDR were successfully analyzed by direct sequencing of amplificates from the explanted liver and from the sequential liver biopsies in a patient with HCV infection recurrence after transplantation. These observations indicate that paraffin-embedded liver tissue, even when stored for more than 20 years, is appropriate for advanced studies on the molecular biology of HCV. (Lab Invest 2000, 80:851-856).

$C$ urrently available information on the molecular biology of the hepatitis $\mathrm{C}$ virus (HCV) in the liver has been generated mainly by studies carried out in frozen liver tissue specimens (Brambilla et al, 1998; Cabot et al, 1997; De Mitri et al, 1998; Okuda et al, 1999; Sakai et al, 1999). Recently, several authors reported that HCV-RNA sequences may also be recovered and amplified by RT-PCR from formalin-fixed, paraffin-embedded (FFPE) liver tissue (Abe et al, 1998; Akyol et al, 1992; Bresters et al, 1992; Edamato et al, 1996; el-Batanony et al, 1994; Guerrero et al, 1997), even when stored for more than 20 years (Mizuno et al, 1998; Soguero et al, 1999). This approach may be

Received January 18, 2000.

Supported in part by grants from CICYT (SAF 97-103) and from FIS (97-2063 and 99-0277). CS was funded by a grant from Fundació Privada Clínic.

Address reprint requests to: Dr. J. C. Sáiz, Liver Unit, Hospital Clinic, Villarroel, 170, 08036 Barcelona, Spain. Fax: 3493 4515522; E-mail: jcsaiz@medicina.ub.es valuable for retrospective studies when frozen liver tissue or serum are not available.

Due to the labile nature of RNA and to the high ribonuclease content of some tissues, degradation of RNA in FFPE specimens often impairs recovery of appropriately preserved target RNA sequences. Several factors, such as delay before fixation, prolonged fixation, and old age of the specimens may favor degradation and prevent further analysis of RNA in FFPE tissues. Different strategies, such as prolonged tissue digestion and amplification of only small RNA targets, have been applied to overcome these shortcomings. However, RNA amplification from FFPE tissues more than 10 years old has rarely been achieved, and only the highly conserved $5^{\prime}$ non-coding region (5'NCR) of HCV has so far successfully been amplified from HCV-infected liver tissue (Abe et al, 1998; Bresters et al, 1992; Edamato et al, 1996; Guerrero et al, 1997; Mizuno et al, 1998; Soguero et al, 1999).

The $5^{\prime} \mathrm{NCR}$ is a well-conserved region among HCV isolates (Purcell, 1997). Therefore, identification of this region in the liver is a reliable marker of current $\mathrm{HCV}$ 
infection, but does not provide relevant information about other aspects that may have epidemiological or pathogenic interest.

In the present study, by following a modified protocol to improve extraction and RT-PCR amplification of RNA from paraffin archival liver tissue, we were able to amplify the hypervariable region 1 (HVR-1) of the E2 gene, as well as the interferon-sensitivity determining region (ISDR) of the NS5A gene, in addition to the $5^{\prime}$ NCR. The amplified material enabled further studies, including identification of $\mathrm{HCV}$ genotype by RFLP analysis of the $5^{\prime} \mathrm{NCR}$, and assessment of the genomic evolution of the virus in the infected liver by direct sequence analysis of other genomic viral regions.

\section{Results}

\section{Amplification of $5^{\prime}$ NCR and Genotyping by RFLP}

Adequacy of RNA extraction from liver specimens was assessed by successful amplification of a 191 nucleotide (nt) fragment of albumin mRNA from the 50 samples tested. The 5'NCR of HCV was amplified from needle biopsies in 8 of $11(73 \%)$ patients with chronic non-A, non-B $(C)$ hepatitis, from liver explants in the 16 patients $(100 \%)$ who underwent liver transplantation for HCV-related cirrhosis, and from the four sequential needle biopsies obtained from a patient with recurrent HCV infection after liver transplantation. No amplification signal was obtained from liver biopsies from the 3 patients with chronic non-A, non-B hepatitis, in 8 subjects with normal liver histology, or from the liver explants of 11 patients who underwent transplantation for HCV-unrelated liver diseases.

The relationship between the age and type of the specimen analyzed and the result of the RT-PCR amplification of the 5' NCR of $\mathrm{HCV}$ in patients with HCV-related disease is shown in Table 1. Amplification was achieved in approximately $50 \%$ of the paraffin blocks older than 20 years and in $100 \%$ of the blocks of more recent specimens. HCV genotype was investigated by RFLP analysis of the 5'NCR amplified from liver biopsies in 13 patients. HCV genotype $1 \mathrm{~b}$ was identified in 11 cases, genotype 1a in 1 case, and genotype 1 in the remaining case (HCV subtype could not be determined).

\section{Amplification and Sequence Analysis of HVR-1 and ISDR}

After optimization of RT-PCR conditions, amplification of HVR-1 and ISDR was attempted in the specimens where the 5'NCR was successfully amplified. At least $1 \mu \mathrm{g}$ of total RNA was required for consistent amplification of HVR-1 or ISDR. In preliminary experiments, $190 \mathrm{bp}$ for HVR-1 and $189 \mathrm{bp}$ for ISDR were identified as the optimal target sizes for successful amplification, although longer amplicons were also obtained from liver specimens less than 5 years old (data not shown). The results of amplification of HVR-1 and ISDR are detailed in Table 1, where it is shown that the efficiency of RT-PCR to amplify both regions was quite similar. Successful amplification was related to the time of storage of the liver specimens. The specificity of amplification was confirmed by direct sequence analysis of the PCR products.

To determine whether FFPE liver tissue from infected patients is suitable for evolutionary studies of $\mathrm{HCV}$, one of the patients with HCV-1b-related cirrhosis that developed recurrent infection after liver transplantation was studied. Direct sequence analysis of HVR-1 and ISDR was performed using RNA extracted from the liver explant and from four post-transplant biopsies sequentially obtained during a seven-year follow-up period. The longitudinal intersample variability of each region was estimated by comparing the sequences obtained from sequential biopsies with the consensus sequence from the explanted liver. Data showed that the rate of fixation of mutations in the HVR-1 (0.26 to $7.50 \times 10^{-2}$ substitutions/nt/year) was greater than in the ISDR $\left(0.08\right.$ to $7.05 \times 10^{-2}$ substitutions/nt/year) (Fig. 1).

\section{Discussion}

PCR amplification of nucleic acid sequences from host or microbial agents present in FFPE tissues is a useful tool for retrospective analysis of archival spec-

Table 1. RT-PCR Amplification of the 5'NCR, HVR-1, and ISDR of HCV in Formalin-Fixed, Paraffin Embedded Liver Tissue

\begin{tabular}{clcccc}
\hline \multirow{2}{*}{$\begin{array}{c}\text { Region } \\
\text { analyzed }\end{array}$} & $\begin{array}{c}\text { Type of } \\
\text { Specimen }\end{array}$ & \multicolumn{3}{c}{ Age of the specimen (years) } \\
\cline { 3 - 5 } 5'NCR & Less than 5 & 5 to 10 & 11 to 20 & More than 20 \\
& Needle biopsy & $8 / 8$ & $7 / 7$ & $1 / 1$ & - \\
& Total & $2 / 2^{a}$ & $2 / 2^{a}$ & $4 / 4$ & $4 / 7$ \\
\multirow{3}{*}{ HVR-1 } & $10 / 10$ & $9 / 9$ & $5 / 5$ & $4 / 7$ \\
& Explanted liver & $8 / 8$ & $6 / 7$ & $0 / 1$ & $2 / 4$ \\
& Needle biopsy & $2 / 2^{a}$ & $2 / 2^{a}$ & $4 / 4$ & $2 / 4$ \\
ISDR & Total & $10 / 10$ & $8 / 9$ & $4 / 5$ & - \\
& Explanted liver & $8 / 8$ & $6 / 7$ & $0 / 1$ & $3 / 4$ \\
& Needle biopsy & $2 / 2^{a}$ & $2 / 2^{a}$ & $2 / 4$ & $3 / 4$ \\
\hline
\end{tabular}

Results according to the type and age of the specimen.

${ }^{a}$ These biopsies were sequentially obtained from the same patient. 
HVR -1

Rate of fixation of mutations (substitutions/nt/year)

Intersample

$7.53 \times 10^{-2}$

5. $45 \times 10^{-2}$

$0.42 \times 10^{-2}$

1. $67 \times 10^{-2}$

Acummulated
$7.53 \times 10^{-2}$
$5.62 \times 10^{-2}$
$1.09 \times 10^{-2}$
$0.27 \times 10^{-2}$

AA number

Liver

explant

1 month

1 year

4 years

7 years

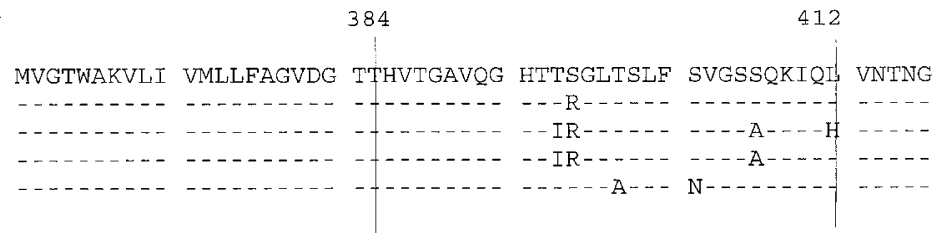

ISDR

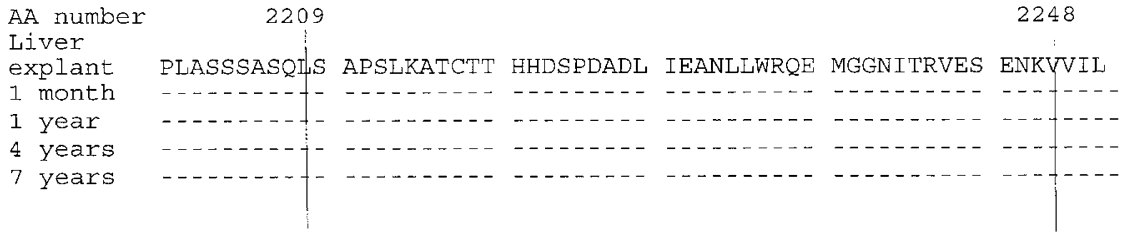

\section{Figure 1.}

Rates of fixation of mutations and amino acid sequences of the hypervariable region 1 (HVR-1) and the interferon sensitivity-determining region (ISDR) from formalin-fixed, paraffin-embedded (FFPE) explanted liver and sequential liver biopsies from a patient who developed hepatitis $\mathrm{C}$ virus (HCV) infection recurrence after liver transplantation for HCV genotype $1 \mathrm{~b}$ induced cirrhosis. Samples were taken during a 7-year follow-up period. Post-transplant sequences are aligned to the explant sequence. Dashes indicate sequence identity; amino acids that differ from the explant sequence are shown. Intersample and accumulated rates of fixation of mutations were deduced by comparison with the sequences from the previous liver sample or from the explanted liver, respectively.

imens (Mies, 1994). However, RT-PCR amplification of RNA from this material is a complex procedure that may be adversely influenced by several factors, mainly by nucleic acid breakdown during tissue processing and storage (Aurer et al, 1993).

$A$ recent extensive analysis of human and viral genes in FFPE tissue sections showed that amplification can be achieved most consistently by using primers that encompass small (less than 200 bp) RNA targets (Krafft et al, 1997). In agreement with these observations, we showed that a highly sensitive RTPCR amplification of the 5'NCR of HCV from very old FFPE liver biopsies may be achieved by targeting a short RNA sequence (Soguero et al, 1999). Amplification of either the core or NS3 regions of HCV was not achieved in an early study (Akyol et al, 1992), probably because the size of the targeted RNA was too large (400 and 590 nt, respectively). In the current study, we used a nested PCR procedure in which the outer primers were designed to delimit a PCR product of $237 \mathrm{nt}$ for HVR-1 and $260 \mathrm{nt}$ for ISDR, and the inner primers were designed to delimit products of $190 \mathrm{nt}$ and $189 \mathrm{nt}$, respectively. The efficiency of the amplification of HVR-1 and ISDR, for similar nt lengths, was equally high for both regions, indicating that selection of a small size target RNA is crucial for successful amplification. Recently, recovery of only small-sized RNA sequences of the Spanish influenza virus from a victim of the 1918 pandemic (Taubenberger et al, 1997) also suggests that the length of the target is more important than the age of the sample for RNA studies in FFPE specimens.

A short time interval between sampling and fixation also seems to be important for efficient amplification (Krafft et al, 1997; Mizuno et al, 1998). The needle liver biopsies analyzed in the present study were immediately fixed in formalin after being taken, and the fixation time was no longer than 24 hours. Successful amplification of HVR1 and ISDR in liver biopsies that were stored for more than 20 years indicates that the RNA was appropriately preserved even in these specimens. The small size of needle biopsies may be another drawback for efficient amplification, which may partially be overcome by intensive extraction of cellular RNA through prolonged proteolytic digestion of the samples (Soguero et al, 1999).

In our study, under optimized RNA extraction and RT-PCR conditions, HVR1 and ISDR amplification was achieved, depending on the age of the material, in $50 \%$ to $100 \%$ of the samples where 5'NCR amplification was previously demonstrated. Amplification of these regions was slightly less efficient than amplification of $5^{\prime} \mathrm{NCR}$, because $100 \mathrm{ng}$ of total RNA was sufficient to amplify the 5'NCR (Soguero et al, 1999) whereas at least $1 \mu \mathrm{g}$ of total RNA was required for HVR-1 or ISDR. Suboptimal amplification of these regions may be related to its higher genetic variability, which might have caused inadequate matching of primers to target sequence in some samples. However, in contrast to HVR-1 and ISDR, where secondary structure requirements have not been described, the $5^{\prime} \mathrm{NCR}$ is a highly structured region that includes an internal ribosome entry site element, which is essential for viral transcription (Reynolds et al, 1995; Sáiz et al, 1999). This tight conformational structure of 5 'NCR may facilitate preservation of this region in stored specimens.

cDNA amplified from FFPE blocks has been used in complex molecular biology studies, such as Southern blot experiments (Akyol et al, 1992; Guerrero et al, 1997; Krafft et al, 1997) or quantitative analysis (Stanta and Bonin, 1998), and may also be cloned (Taubenberger et al, 1997). As shown in the present study, cDNA amplified from HCV-infected FFPE liver tissue can be used to identify the viral genotype or can be used for evolutionary analysis of $\mathrm{HCV}$, by direct se- 
quencing of appropriate $\mathrm{HCV}$ genomic regions in sequential liver samples.

Genotype 1b was the most frequently identified HCV genotype by RFLP analysis of 5'NCR amplified from FFPE liver tissue, in close agreement with the results of HCV genotype studies carried out in serum samples from our geographical area (López-Labrador et al, 1997). Identification of HCV subtype was not achieved in 1 of the 13 cases analyzed, therefore, further studies are necessary to evaluate the performance of other genotyping techniques in HCV material retrieved from paraffin-embedded archival specimens.

Demonstration that HVR-1 and ISDR may be amplified and sequenced in HCV-infected FFPE liver tissue deserves further comment, because the biological importance of these regions is increasingly being recognized. The HVR-1 of HCV is a major immunogenic domain, bears major neutralizing epitopes (Kato et al, 1993; Shimizu et al, 1994), and evolutionary changes of this region are believed to have important implications in viral persistence and pathogenicity (Gretch et al, 1996; Kato et al, 1994; McAllister et al, 1998; Tsai et al, 1998). The role of the ISDR in the response to interferon is still a matter of controversy (Brechot, 1999; Enomoto et al, 1996; Hoofnagle, 1997; Sáiz et al, 1998), but this region seems to modulate the interferon transduction pathway by interacting with a cellular protein kinase (Gale et al, 1997, 1998).

Analysis of the genomic evolution of HVR-1 and ISDR in four biopsies taken during a 7-year follow-up period from a patient with post-transplant HCV recurrence showed that the rate of fixation of mutations in the HVR1 was higher than in the ISDR. Although no amino acid replacement was observed in the ISDR, amino acid fluctuations occurred in the HVR-1. These observations indicate that FFPE liver tissue is suitable for evolutionary analysis of HCV in infected patients.

$\mathrm{HCV}$ infection recurrence after liver transplantation for $\mathrm{HCV}$-induced cirrhosis is among the most important and unsolved problems of clinical Hepatology. Genetic diversification of HCV, which is usually measured in the HVR-1, seems to play an important role in the pathogenesis of this condition (Gretch et al, 1996). Recent observations suggest that an increased HCV genetic diversification may be associated with a more benign course of recurrent HCV hepatitis (SánchezFueyo et al, unpublished observations; Sullivan et al, 1998). So far, the diversification of HVR-1 in patients with post-transplant HCV recurrence has been studied by analysis of sequential serum samples, but studies in liver tissue, where HCV infection takes place, have not been performed. It has also been shown that HCV populations may be different in serum and liver (Cabot et al, 1997; Sakai et al, 1999). Therefore, studies based on amplification and sequence analysis of HVR-1 in FFPE liver tissue may provide new insight into the role of viral diversification in patients with post-transplant HCV infection recurrence and in other clinical situations.

\section{Materials and Methods}

\section{Archival Specimens}

Fifty FFPE liver specimens, including 27 liver explants and 23 needle biopsies were studied. Liver explants were obtained from patients who underwent liver transplantation between 1988 and 1996 (16 had HCVrelated cirrhosis, 5 had HBV-related cirrhosis, 4 had alcoholic cirrhosis, 1 had primary biliary cirrhosis, and 1 had primary sclerosing cholangitis). HCV-RNA was demonstrated in all of the patients with HCV-induced cirrhosis when their sera were tested retrospectively. Needles biopsies were obtained between 1971 and 1985 from 11 patients with chronic non-A, non-B hepatitis (who subsequently were diagnosed as chronic hepatitis $\mathrm{C}$, with positive anti-HCV and HCVRNA in serum), and from 8 patients with normal liver histology and no serological evidence of current HBV or HCV infection. Four additional trucut liver biopsies were serially obtained over a period of 7 years from a single patient who developed recurrent HCV infection after liver transplantation for HCV-related cirrhosis.

\section{Isolation of RNA from Tissue}

Total cellular RNA was extracted from $10 \mu \mathrm{m}$-thick sections by proteolytic enzymatic digestion, as previously described (Soguero et al, 1999). Briefly, tissue was dewaxed with changes of xylene and sections were resuspended in digestion buffer consisting of $10 \mathrm{~mm}$ Tris- $\mathrm{HCl}$ (pH 8.0), 1 mm EDTA ( $\mathrm{pH} 8.0$ ), 0.5\% SDS, and $0.2 \mathrm{mg} / \mathrm{ml}$ of proteinase $\mathrm{K}$. The incubation was carried out in a water bath at $42^{\circ} \mathrm{C}$ for 4 days. Nucleic acids were extracted with phenol/chloroform, followed by overnight precipitation in isopropanol and glucogen. The pellet was washed once in $70 \%$ ethanol, air-dried, and resuspended in sterile diethylpyrocarbonate-treated water. The total amount of isolated RNA was measured by spectrophotometry at $260 \mathrm{~nm}$.

\section{Amplification of HCV Genomic Regions}

HCV-RNA from liver and serum was amplified by RT-PCR using primers derived from the 5'-NCR as previously described (Sánchez-Tapias et al, 1996; Soguero at al, 1999). The HVR-1 was amplified by nested PCR using the following primers: HV7 (outer sense, nt 1396 to 1417) 5'-ACT GGG GAG TCC TGG CGG GCC T-3'; HV5C (outer antisense, nt 1611 to 1633) 5'-TCA TTG CAA TTC AGG GCA GTC CT-3'; HV3B (inner sense, nt 1431 to 1453) 5'-ATG GTG GGT ACC TGG GCT AAG GT-3'; and HV6B (inner antisense, nt 1598 to 1621) 5'-AGG GAA TTC CTG TTG ATG TGC CA-3'. The expected sizes of the PCR products were $237 \mathrm{bp}$ and $190 \mathrm{bp}$, respectively. The ISDR was amplified using primer SEQ2 (outer sense, nt 6906 to 6925) 5'-AGG CTG GCT AGG GGG TCT CC-3', IS3 (outer antisense, nt 7145 to 7165 ) 5'-AGG ATC TCC GCC GCA ACG GAT-3', IS1 (inner sense, nt 6931 to 6950$)$ 5' -CCT TGG CCA GCT CTT CAG CT-3' and IS2 (inner antisense, nt 7101 to 7120) 5'-CGA AGC GGG TCA AAA GAG TC-3'. The expected sizes 
of the PCR products were $259 \mathrm{bp}$ and $189 \mathrm{bp}$, respectively. Nt positions are according to Okamoto et al (Okamoto et al, 1992).

Optimized RT-PCR conditions for both HVR-1 and ISDR were similar to those previously described for the 5'NCR (Soguero et al, 1999). Briefly, for cDNA synthesis, $1 \mu \mathrm{g}$ of total RNA was denatured at $70^{\circ} \mathrm{C}$ for 5 minutes and cooled on ice. The reverse transcription reaction was performed with $300 \mathrm{U}$ of Moloney Murine Leukemia Virus reverse transcriptase (GIBCOBRL, Gaithersburgh, Maryland), random hexanucleotides (Boehringer Mannheim, Manheim, Germany), and $20 \mathrm{U}$ of ribonuclease inhibitor (RNAsin; Promega, Madison, Wisconsin) in a final volume of $25 \mu \mathrm{L}$. The mixture was incubated for 90 minutes at $37^{\circ} \mathrm{C}$, followed by 10 minutes at $95^{\circ} \mathrm{C}$. The PCR reaction was performed in a separated tube with $1.5 \mathrm{U}$ of Taq polymerase (GIBCO-BRL) in a final volume of $50 \mu \mathrm{l}$. PCR parameters were as follows: an initial 5 minutes at $94^{\circ} \mathrm{C}$ followed by 35 cycles of 1 minute at $94^{\circ} \mathrm{C}$, 1.5 minutes at $55^{\circ} \mathrm{C}$, and 1.5 minutes at $72^{\circ} \mathrm{C}$, with $\mathrm{a}$ final 10 -minute completion step at $72^{\circ} \mathrm{C}$. A $5 \mu \mathrm{l}$ aliquot was re-amplified in a $50 \mu$ l reaction mixture with the following cycling parameters: an initial 5 minutes at $94^{\circ} \mathrm{C}$ followed by 35 cycles of 1 minute at $94^{\circ} \mathrm{C}, 1$ minute at $55^{\circ} \mathrm{C}$, and 1 minute at $72^{\circ} \mathrm{C}$, with a final 10 -minute completion step at $72^{\circ} \mathrm{C}$. Amplified products were subjected to electrophoresis on $1.5 \%$ agarose gel stained with ethidium bromide.

Amplification of a $191 \mathrm{nt}$ albumin mRNA fragment was performed in every experiment as a housekeeping gene control (Soguero et al, 1999). To prevent contamination, universally accepted guidelines (Kwok and Higuchi, 1989) were strictly followed, including the use of different blades for sectioning each sample and the use of separated rooms for nucleic acid extraction, amplification, and analysis. All RNA extractions and amplifications were repeated on three separate occasions to ensure reproducibility.

\section{HCV Genotype and Sequence Analysis}

HCV genotype was determined by RFLP analysis of 5'NCR amplificates, as previously described (Thiers et al, 1997). For sequence analysis, specific HVR-1 and ISDR bands were excised from the gel and purified using the CONCERT Rapid Gel extraction kit (GIBCO $B R L$, Karlsruhe, Germany), then directly sequenced using the Rhodamine Terminator Cycle sequencing kit (Perkin Elmer Applied Biosystems, Warrington, United Kingdom) in a 310 DNA sequencer (Applied Biosystems, Westerstad, Germany). Sequence editing was performed using Sequence Navigator (Applied Biosystems, Warrington, United Kingdom).

\section{References}

Abe K, Edamato Y, Park YN, Nomura AMY, Casanovas Taltavull T, Tani M, and Thung SN (1998). In situ detection of hepatitis B, C, and G virus nucleic acids in human hepatocellular carcinoma tissues from different geographic regions. Hepatology 28:568-572.
Akyol G, Dash S, Shieh YS, Malter JS, and Gerber MA (1992). Detection of hepatitis $C$ virus RNA sequences by polymerase chain reaction in fixed liver tissue. Mod Pathol 5:501-504.

Aurer I, Juhbashi T, Sekine I, Tomonaga M, and Gale RP (1993). Analysis of $B C R / A B L$ abnormalities in mRNA from 20-year-old paraffin-embedded tissue for $B C R / A B L$ rearrangement by polymerase chain reaction. Acta Haematol 90:5-7.

Brambilla S, Bellati G, Asti M, Lisa A, Candusso ME, D'Amico M, Grassi G, Giacca M, Franchini A, Bruno S, Ideo G, Mondelli M, and Silini EM (1998). Dynamics of hypervariable region 1 variation in hepatitis $C$ virus infection and correlation with clinical and virological features of liver disease. Hepatology 27:1678-1686.

Brechot C (1999). The direct interplay between HCV NS5A protein and interferon transduction signal: From clinical to basic science. J Hepatol 30:1152-1154.

Bresters D, Cuypers HT, Reesink HW, Chamuleau RA, Schipper ME, Boeser-Nunnink BD, Lelie PN, and Jansen PL (1992). Detection of hepatitis $C$ viral RNA sequences in fresh and paraffin-embedded liver biopsy specimens of non-A, non-B hepatitis patients. J Hepatol 15:391-395.

Cabot B, Esteban JI, Martell M, Genesca J, Vargas V, Esteban R, Guardia J, and Gomez J (1997). Structure of replicating hepatitis $\mathrm{C}$ virus $(\mathrm{HCV})$ quasispecies in the liver may not be reflected by analysis of circulating HCV virions. $\mathrm{J}$ Virol 71:1732-1734.

De Mitri MS, Mele L, Chen $\mathrm{CH}$, Piccinini A, Chianese R, D'Errico A, Alberti A, and Pisi E (1998). Comparison of serum and liver hepatitis $C$ virus quasispecies in HCV-related hepatocellular carcinoma. J Hepatol 29:887-892.

Edamato Y, Tani M, Kurata T, and Abe K (1996). Hepatitis C and $B$ virus infections in hepatocellular carcinoma. Analysis of direct detection of viral genome in paraffin embedded tissues. Cancer 77:1787-1791.

el-Batanony $\mathrm{MH}$, Savage $\mathrm{K}$, Jacobs $\mathrm{R}$, el-Refaie $A O$, Squadrito GG, Brown D, Saleh SM, Raouf AA, Amer KM, and Dusheiko GM (1994). Hepatitis C virus-polymerase chain reaction of routinely processed liver biopsies. J Med Virol 43:380-385.

Enomoto N, Sakuma I, Asahina Y, Kurosaki M, Murakami T, Yamamoto C, Ogura Y, Izumi N, Marumo F, and Sato C (1996). Mutations in the nonstructural protein $5 \mathrm{~A}$ gene and response to interferon in patients with chronic hepatitis $\mathrm{C}$ virus $1 \mathrm{~b}$ infection. N Engl J Med 334:77-81.

Gale MJ, Blakely CM, Kwieciszewski B, Tan SL, Dossett M, Tang NM, Korth MJ, Polyak SJ, Gretch DR, and Katze MG (1998). Control of PKR protein kinase by the hepatitis $C$ virus nonstructural 5A protein: Molecular mechanisms of kinase regulation. Mol Cell Biol 18:5208-5218.

Gale MJ, Korth MJ, Tang NM, Hopkins DA, Dever TE, Polyak SJ, Gretch DR, and Katze MG (1997). Evidence that hepatitis $C$ virus resistance to interferon is mediated through repression of the PKR protein kinase by the nonstructural $5 \mathrm{~A}$ protein. Virology 230:217-227.

Gretch D, Polyak SJ, Wilson JJ, Carithers R Jr, Perkins JD, and Corey L (1996). Tracking hepatitis $C$ virus quasispecies major and minor variants in symptomatic and asymptomatic liver transplant recipients. J Virol 70:7622-7631.

Guerrero RB, Batts KP, Brandhagen DJ, Germer JJ, Pérez $R G$, and Persing DH (1997). Effects of formalin fixation and 
prolonged block storage on detection of hepatitis $\mathrm{C}$ virus RNA in liver tissue. Diagn Mol Pathol 6:277-281.

Hoofnagle JH (1997). The interferon sensitivity determining region: All hepatitis $\mathrm{C}$ virus isolates are not the same. Hepatology 25:769-771.

Kato N, Ootsuyama Y, Sekiya H, Ohkoshi S, Nakazawa T, Hijikata M, and Shimothono K (1994). Genetic drift in the hypervariable region 1 of the viral genome in persistent hepatitis $\mathrm{C}$ virus infection. J Virol 68:4776-4784.

Kato N, Sekiya H, Ootsuyama Y, Nakazawa T, Hijikata M, Ohkoshi S, and Shimothono K (1993). Humoral immune response to hypervariable region 1 of the putative envelope glycoprotein (gp70) of hepatitis C virus. J Virol 67:3923-3930.

Krafft AE, Duncan BW, Bijwaard KE, Taubenberger JK, and Lichy JH (1997). Optimization of the isolation and amplification of RNA from formalin-fixed, paraffin-embedded tissue: The Armed Forces Institute of Pathology experience and literature review. Mol Diagnosis 2:217-230.

Kwok S and Higuchi R (1989). Avoiding false positives with PCR. Nature 339:237-238.

López-Labrador FX, Ampurdanés S, Forns X, Castells A, Sáiz JC, Costa J, Bruix J, Sánchez-Tapias JM, Jiménez de Anta MT, and Rodés J (1997). Hepatitis C virus (HCV) genotypes in Spanish patients with HCV infection: Relationship between HCV genotype $1 \mathrm{~b}$, cirrhosis and hepatocellular carcinoma. J Hepatol 27:959-965.

McAllister J, Casino C, Davidson F, Power J, Lawlor E, Yap PL, Simmonds P, and Smith DB (1998). Long-term evolution of the hypervariable region of hepatitis $C$ virus in a commonsource-infected cohort. J Virol 72:4893-4905.

Mies C (1994). Molecular biological analysis of paraffinembedded tissues. Hum Pathol 25:555-560.

Mizuno T, Nagamura H, Iwamoto KS, Ito T, Fukuhara T, Tokunaga M, Tokuoka S, Mabuchi K, and Seyama T (1998). RNA from decades-old archival tissue blocks for retrospective studies. Diagn Mol Pathol 7:202-208.

Okamoto H, Kojima M, Okada S, Yoshizawa H, lizuka $H$, Tanaka T, Muchmore EE, Peterson DA, Ito Y, and Mishiro S (1992). Genetic drift of hepatitis C virus during an 8.2 year infection in a chimpanzee: Variability and stability. Virology 190:894-899.

Okuda M, Hino K, Korenaga M, Yamaguchi Y, Kato Y, and Okita K (1999). Differences in hypervariable region 1 quasispecies of hepatitis $\mathrm{C}$ virus in human serum, peripheral blood mononuclear cells, and liver. Hepatology 29:217-222.

Purcell R (1997). The hepatitis C virus: Overview. Hepatology 26 (Suppl 1):11S-14S.

Reynolds JE, Kaminski A, Kettinen HJ, Grace K, Clarke BE, Carroll AR, Rowlands DJ, and Jackson RJ (1995). Unique features of internal initiation of hepatitis $C$ virus RNA translation. EMBO J 14:6020.
Sáiz JC, López de Quinto S, Ibarrola N, López-Labrador FX, Sánchez-Tapias JM, Rodés J, and Martinez-Salas E (1999). Internal initiation of translation efficiency in different hepatitis C genotypes isolated from interferon treated patients. Arch Virol 144:215-229.

Sáiz JC, López-Labrador FX, Ampurdanés S, Dopazo J, Forns X, Sánchez-Tapias JM, and Rodés J (1998). The prognostic relevance of the nonstructural $5 \mathrm{~A}$ gene interferon sensitivity determining region is different in infections with genotype $1 \mathrm{~b}$ and $3 \mathrm{a}$ isolates of hepatitis $\mathrm{C}$ virus. $\mathrm{J}$ Infect Dis 177:839-847.

Sakai A, Kaneko S, Honda M, Matsushita E, and Kobayashi K (1999). Quasispecies of hepatitis C virus in serum and in three different parts of the liver of patients with chronic hepatitis. Hepatology 30:556-561.

Sánchez-Tapias JM, Forns X, Ampurdanés S, Titó LI, Planas R, Viver JM, Acero D, Torres M, Mas P, Morillas P, Forné M, Espinós J, Llovet JM, Costa J, Olmedo E, López-Labrador FX, Jiménez de Anta MT, and Rodés J (1996). Low-dose alpha interferon therapy can be effective in chronic hepatitis C. Results of a multicentre, randomised trial. Gut 38:603609.

Shimizu YK, Hijikata M, Iwamoto A, Alter HJ, Purcell RH, and Yoshikura $\mathrm{H}$ (1994). Neutralizing antibodies against hepatitis $C$ virus and the emergence of neutralization escape mutant viruses. J Virol 68:1494-1500.

Soguero C, Ribalta T, Campo E, Sánchez-Tapias JM, Sáiz JC, and Bruguera M (1999). Detection of hepatitis C virus (HCV) RNA in more than 20 year-old archival liver tissue. Lab Invest 79:365-366.

Stanta G and Bonin S (1998). RNA quantitative analysis from fixed and paraffin-embedded tissues: Membrane hybridization and capillary electrophoresis. Biotechniques 24:271276.

Sullivan DG, Wilson JJ, Carithers RL Jr, Perkins JD, and Gretch DR (1998). Multigene tracking of hepatitis C virus quasispecies after liver transplantation: Correlation of genetic diversification in the envelope region with asymptomatic or mild disease patterns. J Virol 72:10036-10043.

Taubenberger JK, Reid AH, Krafft AE, Bijwaard KE, and Fanning TG (1997). Initial genetic characterization of the 1918 "Spanish" Influenza virus. Science 275:1793-1796.

Thiers V, Jaffredo F, Tuveri R, Chodan N, and Brechot C (1997). Development of a simple restriction fragment length polymorphism (RFLP) based assay for HCV genotyping and comparative analysis with genotyping and serotyping tests. J Virol Methods 65:9-17.

Tsai SL, Chen YM, Chen MH, Huang CY, Sheen IS, Yeh CT, Huang JH, Kuo GC, and Liaw YF (1998). Hepatitis C virus variants circumventing cytotoxic $\mathrm{T}$ lymphocyte activity as a mechanism of chronicity. Gastroenterology 115:954-965. 